\title{
Utility of interferon gamma/tumor necrosis factor alpha FluoroSpot assay in differentiation between active tuberculosis and latent tuberculosis infection: a pilot study
}

\author{
Lifan Zhang ${ }^{1,2,3^{\dagger}}$, Shijun Wan $^{1 \dagger}$, Ziyue Zhou ${ }^{4 \dagger}$, Yueqiu Zhang ${ }^{1}$ and Xiaoqing Liu ${ }^{1,2,3^{*}}$
}

\begin{abstract}
Background: The differential diagnosis of active tuberculosis (ATB) and latent tuberculosis infection (LTBI) remains challenging in clinical practice. We aimed to evaluate the diagnostic accuracy of the IFN- $\gamma /$ TNF-a FluoroSpot assay for differentiating ATB from LTBI.

Methods: We conducted a pilot study of case-control design, using the FluoroSpot assay to simultaneously detect IFN- $\gamma$ and TNF-a secretion at the single-cell level. The frequencies of antigen-specific single TNF- $a-$-, total TNF- $a-$, single

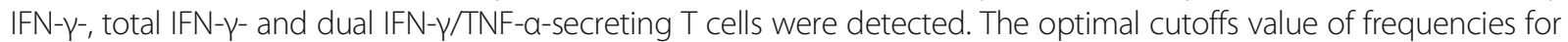
differentiating ATB from LTBI were determined according to receiver operating characteristic curve analysis. The sensitivity, specificity, predictive values (PV) and likelihood ratios (LR) of the FluoroSpot assay were calculated.

Results: Thirty patients diagnosed microbiologically with ATB, 36 healthcare workers with LTBI and 36 healthy controls were enrolled. After stimulated by ESAT-6 or CFP-10 peptides, the median frequencies of single TNF-a-, total TNF-a-,

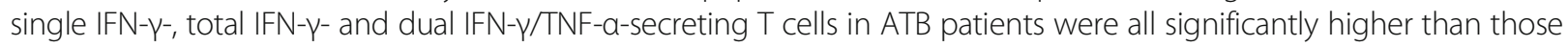
in LTBI and HC groups $(P<0.01)$. The frequencies of total IFN- $\gamma$-secreting T cells detected by FluoroSpot assay correlated significantly with those of T-SPOT.TB ( $r=0.910$ for ESAT-6, $P<0.001, r=0.845$ for CFP-10, $P<0.001)$. After stimulated by ESAT-6 peptides, with total TNF-a-secreting T cells frequencies at a cut off value of $21 \mathrm{iSFCs} / 250,000$ PBMCs, the sensitivity, specificity, PLR, NLR, PPV, NPV of IFN- $\gamma / T N F-a$ FluoroSpot assay in differentiating ATB from LTBI were $96.7 \%$ (95\%Cl, 82.8-99.9\%), 94.3\% (95\%Cl, 80.8-99.3\%), 16.92 (95\%Cl, 4.40-65.08), 0.04 (95\%Cl, 0.01-0.24), 93.6\% (95\%Cl,78.6-99.2\%) and 97.1\% (95\%Cl, 84.7-99.9\%), respectively. With the frequencies of total TNF-a- and total IFN- $\gamma^{-}$ secreting T cells stimulated by ESAT-6 peptides combined, the specificity was increased to $97.1 \%$, and the positive
\end{abstract}

\footnotetext{
*Correspondence: liuxqpumch@126.com; liuxq@pumch.cn

'Lifan Zhang, Shijun Wan and Ziyue Zhou contributed equally to this work.

'Division of Infectious Diseases, Peking Union Medical College Hospital,

Chinese Academy of Medical Sciences \& Peking Union Medical College, Beijing 100730, China

${ }^{2}$ Clinical Epidemiology Unit, International Epidemiology Network, Peking

Union Medical College Hospital, Chinese Academy of Medical Science,

Beijing 100730, China

Full list of author information is available at the end of the article
}

(c) The Author(s). 2021 Open Access This article is licensed under a Creative Commons Attribution 4.0 International License, which permits use, sharing, adaptation, distribution and reproduction in any medium or format, as long as you give appropriate credit to the original author(s) and the source, provide a link to the Creative Commons licence, and indicate if changes were made. The images or other third party material in this article are included in the article's Creative Commons licence, unless indicated otherwise in a credit line to the material. If material is not included in the article's Creative Commons licence and your intended use is not permitted by statutory regulation or exceeds the permitted use, you will need to obtain permission directly from the copyright holder. To view a copy of this licence, visit http://creativecommons.org/licenses/by/4.0/ The Creative Commons Public Domain Dedication waiver (http://creativecommons.org/publicdomain/zero/1.0/) applies to the data made available in this article, unless otherwise stated in a credit line to the data. 
likelihood ratio to 31.5. The combination with CFP-10 might not improve the diagnostic accuracy of the ESAT-6 for differentiating ATB from LTBI.

Conclusions: IFN- - /TNF-a FluoroSpot assay might have potential to help differentiate ATB from LTBI, but the findings need to be further verified by cross-sectional or prospective cohort studies.

Keywords: Tuberculosis, Latent tuberculosis infection, Tumor necrosis factor, Interferon gamma, FluoroSpot, Diagnosis

\section{Background}

Tuberculosis (TB) is known to be the leading cause of death from a single infectious pathogen. Worldwide 10.0 million people were newly diagnosed with TB disease, and TB caused 1.2 million deaths among HIV-negative people in 2019 [1]. China has the second largest number of $\mathrm{TB}$ cases in the world, accounting for $8.4 \%$ of all TB cases [1]. Timely diagnosis and successful treatment could prevent millions of TB deaths each year, but currently there isn't an ideal test for diagnosing TB rapidly and accurately, especially for extrapulmonary TB.

WHO defined LTBI as a state of persistent immune response to stimulation by Mycobacterium. tuberculosis (MTB) antigens with no evidence of clinically manifest ATB [2]. It is estimated that about 23\% (1.7 billion) of the global population have latent TB infection [3]. Tuberculin skin test (TST) and Interferongamma release assay (IGRA) are commonly used to identify TB infection. However, the cross-reactive immune response between purified protein derivative (PPD) and Bacille Calmette-Gue'rin (BCG) may lead to false positive TST results, which may greatly reduce the specificity of TST in China, where BCG vaccination was included in the Newborn Immunization Schedule [4]. IGRA diagnosed TB infection by detecting IFN- $\gamma$ released by MTB-specific antigen stimulation. However, it cannot distinguish ATB with LTBI [5]. Hence, new methods that can accurately differentiate ATB and LTBI are imperative for countries with high TB disease burden like China.

Tumor necrosis factor (TNF) participates in MTB immune response by activating macrophages, inducing chemokines, participating in TB granuloma formation and maintaining granuloma integrity. In addition, animal experiments showed that blocking the TNF signaling pathway accelerated intracellular bacterial growth and necrotic death of overladen macrophages, implicating that TNF restricts mycobacterial growth within macrophages and prevents their necrosis [6]. Human studies demonstrated that patients with rheumatic disease using TNF- $\alpha$ antagonists had an increased risk of ATB and LTBI reactivation [7], suggesting that TNF- $\alpha$ is a key factor in controlling MTB invasion and proliferation. Based on these studies, we hypothesize that the combination of IFN- $\gamma$ and TNF- $\alpha$ may be helpful in the differential diagnosis of ATB and LTBI.

FluoroSpot is a highly sensitive and practical technique based on ELISPOT, which simultaneously detect two or more cytokine secretions at single-cell level. The interpretation of the results is based on the visualization of the cells with distinct fluorescence, thus avoiding color confusion $[8,9]$. FluoroSpot is found to have high consistency with ELISPOT [9]. We aim to evaluate the diagnostic accuracy of IFN- $\gamma /$ TNF- $\alpha$ FluoroSpot assay in differentiating ATB from LTBI, with microbiology as the reference standard.

\section{Participants and methods}

The study was conducted in accordance with the Declaration of Helsinki and was approved by the Ethics Committee of PUMCH (No: S-715). Informed written consent was obtained from all patients prior to their enrollment in this study.

\section{Participants}

From March 2018 to September 2018, ATB patients and healthcare workers were enrolled from Peking Union Medical College Hospital and Beijing Chest Hospital. The inclusion criteria for the active TB group were: 1 ) aged from 18 to 75 years old, AND 2) had typical clinical manifestations of ATB such as cough, chest pain, night sweats, weight loss, etc. AND 3) ATB diagnosis made based on microbiological evidence (including sputum smear-positive, positive MTB culture, positive Nucleic Acid Amplification (NAA) testing or Xpert MTB/RIF assay), AND 4) had not received any anti-TB therapy by the time of recruitment. The inclusion criteria for healthcare workers were: 1) aged from 18 to 75 years old, AND 2) without clinical manifestations suspected of ATB, AND 3) without evidence of previous TB such as self-reported TB history or positive X-ray findings, AND 4) without autoimmune diseases, diabetes mellitus, chronic hepatitis or malignancy. Healthcare workers with positive and negative T-SPOT.TB testing results were regarded as LTBI and healthy controls (HC), respectively. Persons who were pregnant, receiving antiTNF- $\alpha$ therapy, or infected with HIV were excluded. This study was a case-control designed diagnostic accuracy study. 


\section{IFN- $\gamma /$ TNF- $a$ FluoroSpot assay}

Four milliliters of peripheral blood were obtained from each participant by venipuncture. Within $4 \mathrm{~h}$ of sample collection, peripheral blood mononuclear cells (PBMCs) were isolated from heparinized whole blood by density gradient centrifugation. Cell suspension was prepared at $2.5 \times 10^{6} \mathrm{PBMCs} / \mathrm{ml}$ with serum free culture medium $\left(\right.$ Gibco $^{\text {tw }}$ AIM V Medium liquid, Invitrogen, USA, abbreviated as AIM-V). IFN- $\gamma /$ TNF- $\alpha$ FluoroSpot (Mabtech $\mathrm{AB}$, Sweden) assays were performed according to the manufacturer. 96-well plates pre-coated with monoclonal antibodies against IFN- $\gamma$ and TNF- $\alpha$ were seeded with $2.5 \times 10^{5} \mathrm{PBMCs}$ and anti-CD28 (at $0.1 \mu \mathrm{g} / \mathrm{ml}$, Mabtech AB, Sweden). $50 \mu$ of AIM-V (Gibco ${ }^{\mathrm{Tw}}$ AIM V Medium liquid, Invitrogen, USA) as nil control, $5 \mu \mathrm{g} / \mathrm{ml}$ PHA as positive control, and $6-\mathrm{kDa}$ early secreted antigenic target (ESAT-6) and 10-kDa culture filtrate protein (CFP-10) peptides (final concentration at $10 \mu \mathrm{g} / \mathrm{ml}$ of each peptide) as MTB-specific antigens were added in duplicate wells. All peptides were 15mers overlapping their adjacent peptides by 10 amino acids, spanning the length of ESAT-6 (17 peptides) or CFP-10 (18 peptides). The purity of each peptide exceeded $80 \%$, and identity was confirmed by mass spectrometry. Plates were incubated at $37^{\circ} \mathrm{C}$ in $5 \%$ carbon dioxide for $16-20 \mathrm{~h}$ and then washed with washing buffer. After incubation, the detection antibodies (anti-TNF- $\alpha$ biotin and anti-IFN- $\gamma$ FITC) were added to each well and incubated for two hours at room temperature under dark condition. Then streptavidine-550 red-conjugate and anti-FITC-490 green were added to the reaction system. The reaction system was incubated for another one hour under dark and dry condition. Finally, fluorescence enhancer was loaded to make spots visible under the automated ELIS POT reader (AID iSpot, Strassberg, Germany). When counting the frequencies of ESAT-6 or CFP-10 antigenspecific immunofluorescence spot forming cells (iSFCs), including frequencies of total TNF- $\alpha$ - or total IFN- $\gamma-$ or dual IFN- $\gamma /$ TNF- $\alpha$-secreting $T$ cells, the background spots in the nil control well were subtracted. If the number of spots was over 50 iSFCs $/ 2.5 \times 10^{5} \mathrm{PBMC}$ for TNF- $\alpha$ or over 10 iSFCs $/ 2.5 \times 10^{5}$ PBMC for IFN- $\gamma$ in nil control, or less than 200 iSFCs $/ 2.5 \times 10^{5} \mathrm{PBMC}$ in positive control, the result was considered to be indeterminate. Images of the results are presented in Fig. 1.

Laboratory staff who conducted the assays and researchers who interpreted the results were all blinded to patients' clinical data.

\section{Statistical analysis}

We used the histogram to check the distribution of the variables. For normally distributed variables, results were presented as mean \pm standard deviation (SD), while variables with an abnormal distribution were denoted as median and interquartile range (IQR). Categorical data were presented as percentages and 95\% confidence intervals (CIs). We used Mann-Whitney U test to compare the frequencies of iSFCs and Chi-square test to compare response proportions between different groups, respectively. We used Wilcoxon signed-rank test to compare the frequency of iSFCs between the two antigens in the same group. We used Spearman's rank correlation to measure correlation between the frequencies of total IFN- $\gamma$-secreting $\mathrm{T}$ cells detected by FluoroSpot assay and T-SPOT.TB.

Receiver operating characteristic (ROC) curves were used to show the overall accuracy of IFN- $\gamma / \mathrm{TNF}-\alpha$ FluoroSpot assay for differentiating ATB and LTBI in frequencies of $\mathrm{T}$ cells. The areas under the ROC curves (AUROC) of each group of $\mathrm{T}$ cells were calculated and compared. The cutoff value with the largest Youden's index on the ROC curve was regarded as the optimal cutoff of the frequency. The sensitivity, specificity, predictive value (PV) and likelihood ratio (LR) were calculated at the optimal cutoff.

Statistical analyses were performed using SPSS 24.0 (SPSS Inc., Chicago, IL, USA) and MedCalc (version 11, MedCalc Software bvba, Mariakerke, Belgium). $P<0.05$ (two-sided) were considered as statistically significant.

\section{Results}

\section{Demographic and clinical features of participants}

A total of 101 participants, including 30 patients with microbiologically confirmed ATB, 35 participants with LTBI and 36 healthy controls were enrolled. Of the 30 ATB patients, 23 (76.7\%) were positive for MTB culture, 16 (53.3\%) were positive for sputum smear acid-fast staining, $24(80.0 \%)$ were positive for MTB-NAA testing, and $20(66.7 \%)$ were positive for Xpert MTB/RIF test. 27 (90.0\%) ATB patients were diagnosed with pulmonary tuberculosis, while tuberculous lymphadenitis and tuberculous pleuritis were diagnosed in 2(6.7\%) and 1 (3.3\%) patient, respectively. Detailed characteristics of the participants are shown in Table 1.

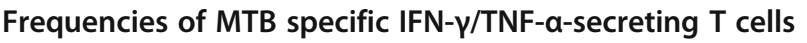
After stimulated by ESAT- 6 or CFP-10 peptides, the frequencies of single TNF- $\alpha$-, total TNF- $\alpha-$, single IFN- $\gamma_{-}^{-}$, total IFN- $\gamma$-, dual IFN- $\gamma /$ TNF- $\alpha$-secreting $\mathrm{T}$ cells in ATB group were significantly higher than those in LTBI group and $\mathrm{HC}$ group $(P<0.01)$. The frequencies of total TNF- $\alpha-$, single IFN- $\gamma^{-}$, total IFN- $\gamma-$, dual IFN- $\gamma /$ TNF- $\alpha-$ secreting $\mathrm{T}$ cell in LTBI group were significantly higher than those in HC group under single ESAT-6 stimulation (Fig. 2, Supplementary Table 1).

In the ATB group, the median frequencies of total TNF- $\alpha$-secreting $\mathrm{T}$ cells was $276[\mathrm{IQR}, 88-581]$ iSFCs/ $2.5 \times 10^{5}$ PBMC when stimulated by ESAT- 6 , compared 


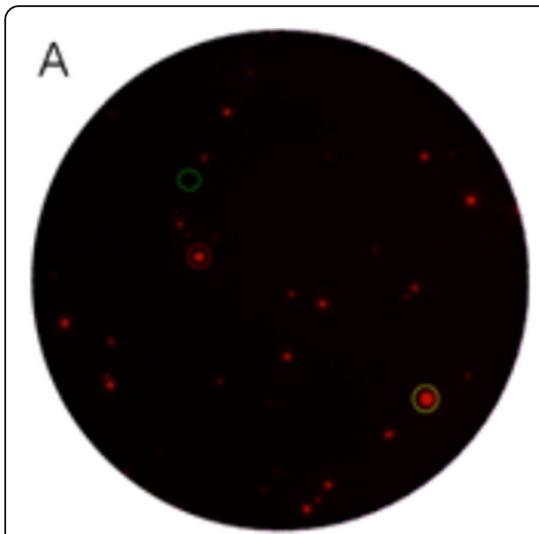

TNF- $\boldsymbol{\alpha}$-Biotin Red

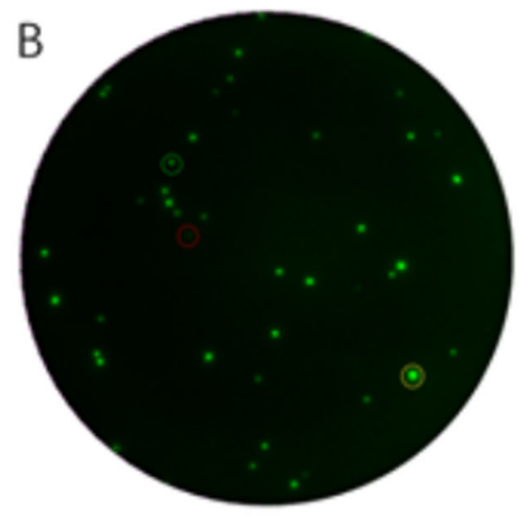

IFN- $\gamma$-FITC Green

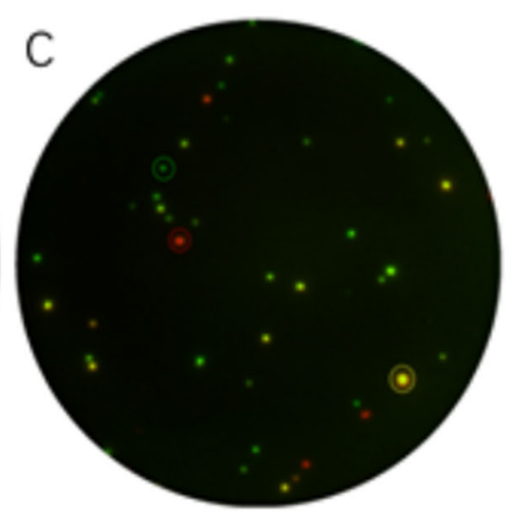

TNF- $\alpha$ \& IFN- $-\gamma$ overlap

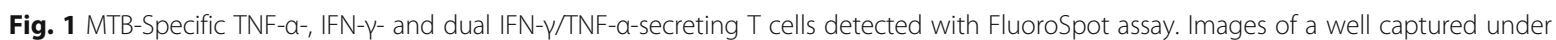
different filters are presented as an example. (A) Red spots represent total TNF-a specific T cells. (B) Green spots represent total IFN- $\gamma$ specific T cells. (C) Overlay of $(\mathbf{A})$ and (B). Yellow spots from superposition of red and green fluorescence represent T cells dually secreting IFN- $\gamma$ and TNF-a after stimulation. Single cytokine (TNF-a or IFN- $\gamma$ ) secreting $T$ cell frequencies equals the frequencies of dual secreting $T$ cells subtracted from total T cells

to only $109[\mathrm{IQR}, 40-210] \mathrm{iSFCs} / 2.5 \times 10^{5}$ PBMC stimulated by CFP-10 $(P=0.001)$. In consistency with the result, the median frequencies of single TNF- $\alpha$-secreting $T$ cells stimulated by ESAT-6 were significantly higher than those stimulated by CFP-10 $(P<0.001)$ (Fig. 2$)$.

There was no indeterminate result of IFN- $\gamma /$ TNF- $\alpha$ FluoroSpot assay in all 101 study samples. When counting the frequencies of TNF- $\alpha$-secreting $\mathrm{T}$ cells in nil control wells, 38.6\% (39 in 101) displayed over $10 \mathrm{iSFCs} / 2.5 \times 10^{5} \mathrm{PBMC}$, and the median frequencies of TNF- $\alpha$-secreting $\mathrm{T}$ cells in ATB, LTBI and HC groups were 24[IQR, 6-39], 4[IQR, 0-11] and 4[IQR,
1-11] iSFCs $/ 2.5 \times 10^{5}$ PBMC, respectively. (Supplementary Table 2).

\section{Comparison of MTB specific IFN- $\gamma$ response between FluoroSpot assay and T-SPOT.TB}

After stimulated by ESAT- 6 or CFP-10 peptides, the frequencies of total IFN- $\gamma$-secreting $\mathrm{T}$ cells detected by FluoroSpot assay strongly and significantly correlated with those of T-SPOT.TB $(r=0.910$ for ESAT-6, $P<$ $0.001, r=0.845$ for CFP-10, $P<0.001$ ) (Fig. 3). The agreement between the results of FluoroSpot assay and T-SPOT.TB was almost perfect $(\mathrm{kappa}=0.852, p<$

Table 1 Characteristics of participants

\begin{tabular}{|c|c|c|c|c|}
\hline Characteristics & $\begin{array}{l}\text { ATB } \\
(n=30)\end{array}$ & $\begin{array}{l}\text { LTBI } \\
(n=35)\end{array}$ & $\begin{array}{l}\mathrm{HC} \\
(n=36)\end{array}$ & $\begin{array}{l}\text { Total } \\
(n=101)\end{array}$ \\
\hline $\operatorname{Sex}(M / F)$ & $13 / 17$ & $4 / 31$ & $8 / 28$ & $25 / 76$ \\
\hline Age (mean $\pm S D)$ & $48 \pm 18$ & $40 \pm 9$ & $36 \pm 10$ & $41 \pm 13$ \\
\hline \multicolumn{5}{|l|}{ Complications (n, \%) } \\
\hline Malignancy & $0(0.0 \%)$ & $0(0.0 \%)$ & $0(0.0 \%)$ & $0(0.0 \%)$ \\
\hline Renal failure & $0(0.0 \%)$ & $0(0.0 \%)$ & $0(0.0 \%)$ & $0(0.0 \%)$ \\
\hline Diabetes mellitus & $1(3.3 \%)$ & $0(0.0 \%)$ & $0(0.0 \%)$ & $1(1.0 \%)$ \\
\hline TB history & $2(6.7 \%)$ & $0(0.0 \%)$ & $0(0.0 \%)$ & $2(2.0 \%)$ \\
\hline Autoimmune diseases & $1(3.3 \%)$ & $0(0.0 \%)$ & $0(0.0 \%)$ & $1(1.0 \%)$ \\
\hline Corticosteroid therapy & $1(3.3 \%)$ & $0(0.0 \%)$ & $0(0.0 \%)$ & $1(1.0 \%)$ \\
\hline Immunosuppressants & $0(0.0 \%)$ & $0(0.0 \%)$ & $0(0.0 \%)$ & $0(0.0 \%)$ \\
\hline \multicolumn{5}{|l|}{ Blood tests } \\
\hline $\mathrm{WBC}\left({ }^{*} 10^{9} / \mathrm{L}\right)$ & $6.96 \pm 2.50$ & $6.31 \pm 1.63$ & $6.51 \pm 1.83$ & $6.59 \pm 2.01$ \\
\hline Lymphocyte $\left({ }^{*} 10^{9} /\right.$ L) & $1.49 \pm 0.58$ & $2.01 \pm 0.45$ & $2.23 \pm 0.63$ & $1.91 \pm 0.63$ \\
\hline
\end{tabular}

Abbreviations: ATB, active tuberculosis; LTBI, latent tuberculosis infection; HC, healthy controls; M, male; F, female; SD, standard deviation; TB, tuberculosis; WBC, white blood cell 

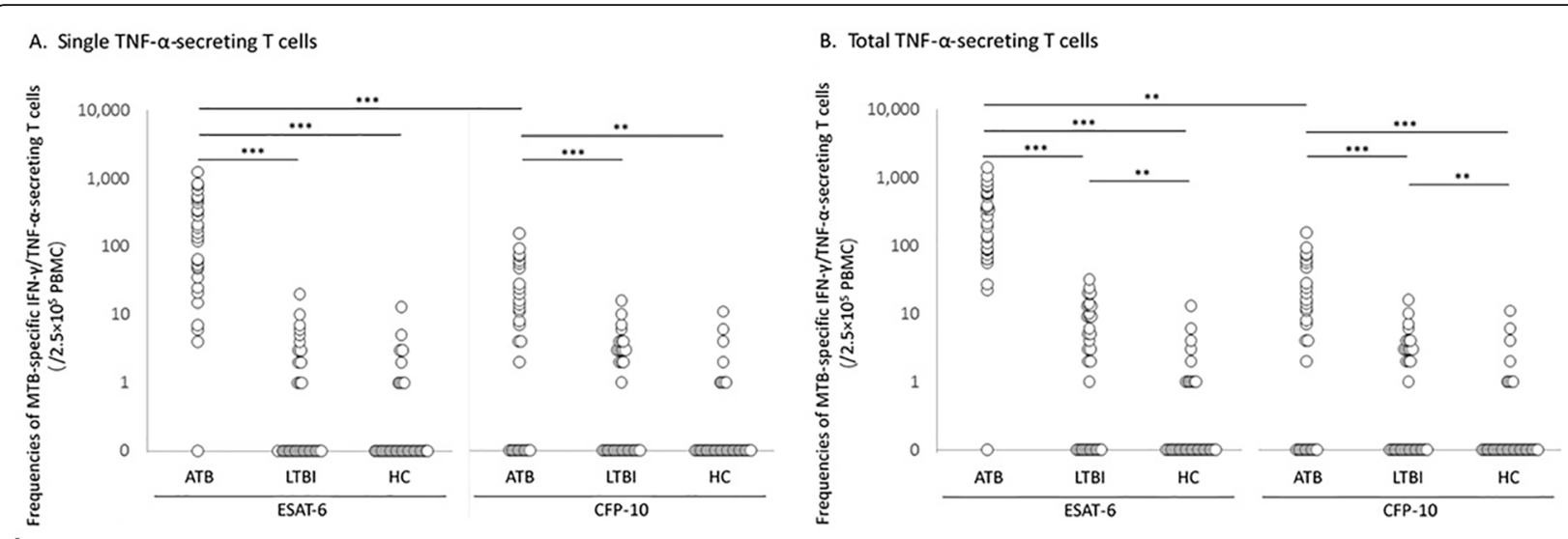

C. Single IFN- $\gamma$-secreting T cells

D. Total IFN- - -secreting T cells
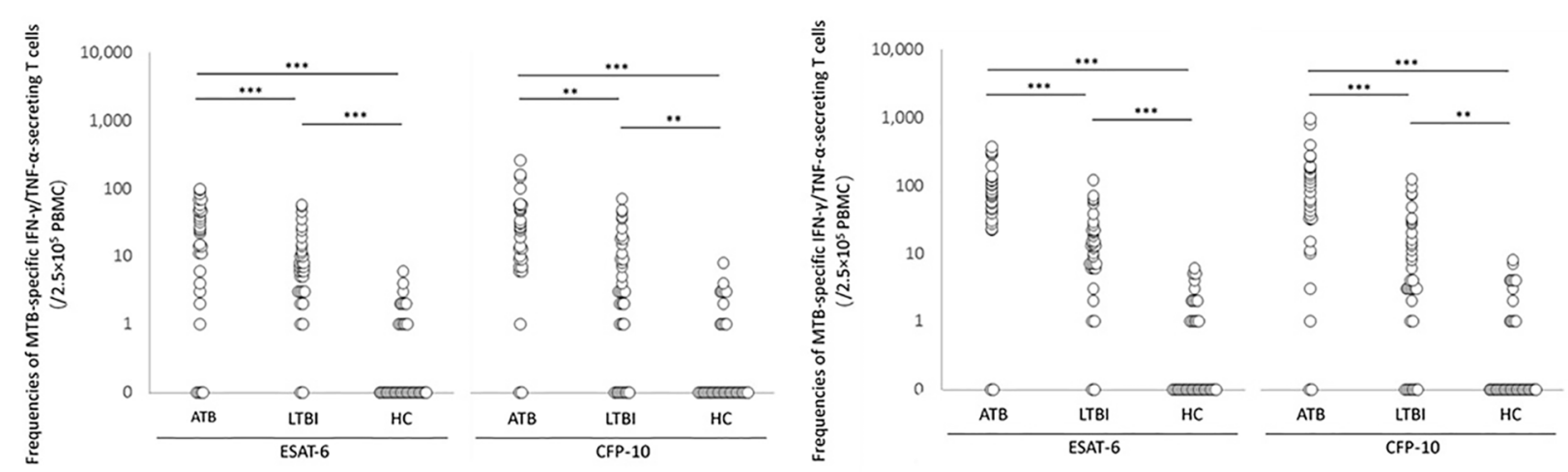

E. Dual IFN- $\gamma /$ TNF- $\alpha$-secreting T cells

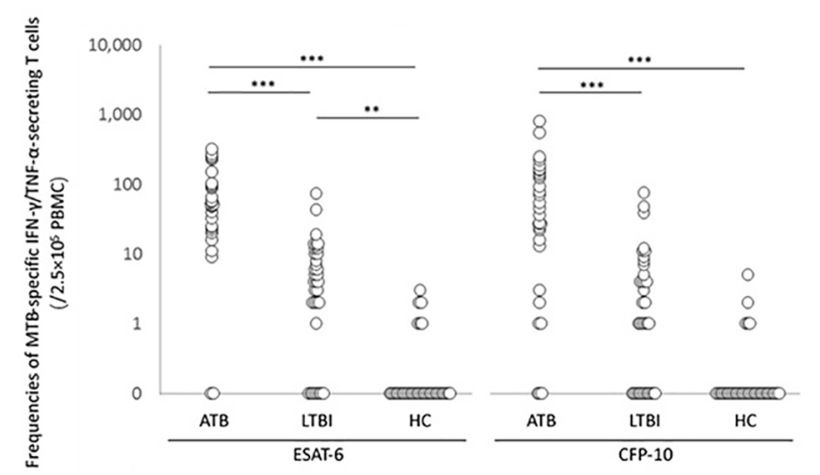

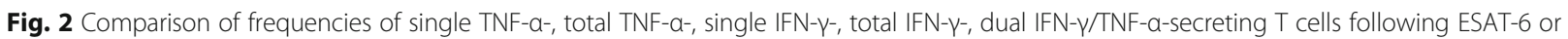
CFP-10 stimulation in ATB, LTBI and HC groups. T cell frequencies are estimated as per $2.5 \times 10^{5}$ PBMC. Each point represents a sample. (A) Frequencies of $T$ cells secreting only TNF-a, without IFN- $\gamma$. (B) Frequencies of all the T cells secreting TNF-a, with or without IFN- $\gamma$ secretion. (C) Frequencies of T cells secreting only IFN- $\gamma$, without TNF-a. (D) Frequencies of all the T cells secreting IFN- $\gamma$, with or without TNF-a secretion. (E) Frequencies of T cells secreting both IFN- $\gamma$ and TNF-a simultaneously. Abbreviations: ATB, Active tuberculosis; LTBI, latent tuberculosis infection; HC, healthy control; MTB, mycobacterium.tuberculosis. ${ }^{* * *} P<0.001,{ }^{* *} P<0.01$

0.001). In active TB group, the sensitivity of Fluorospot assay detecting total IFN- $\gamma$-secreting $\mathrm{T}$ cell was $93.3 \%$, and there was no significant difference compared with T-SPOT.TB $(96.7 \%, P=1.000)$.
Diagnostic accuracy of IFN- $\gamma /$ TNF- $a$ FluoroSpot assay in distinguishing ATB from LTBI

In the ATB and LTBI groups, the AUROC of the frequencies of ESAT-6-specific total TNF- $\alpha$-secreting T cell 


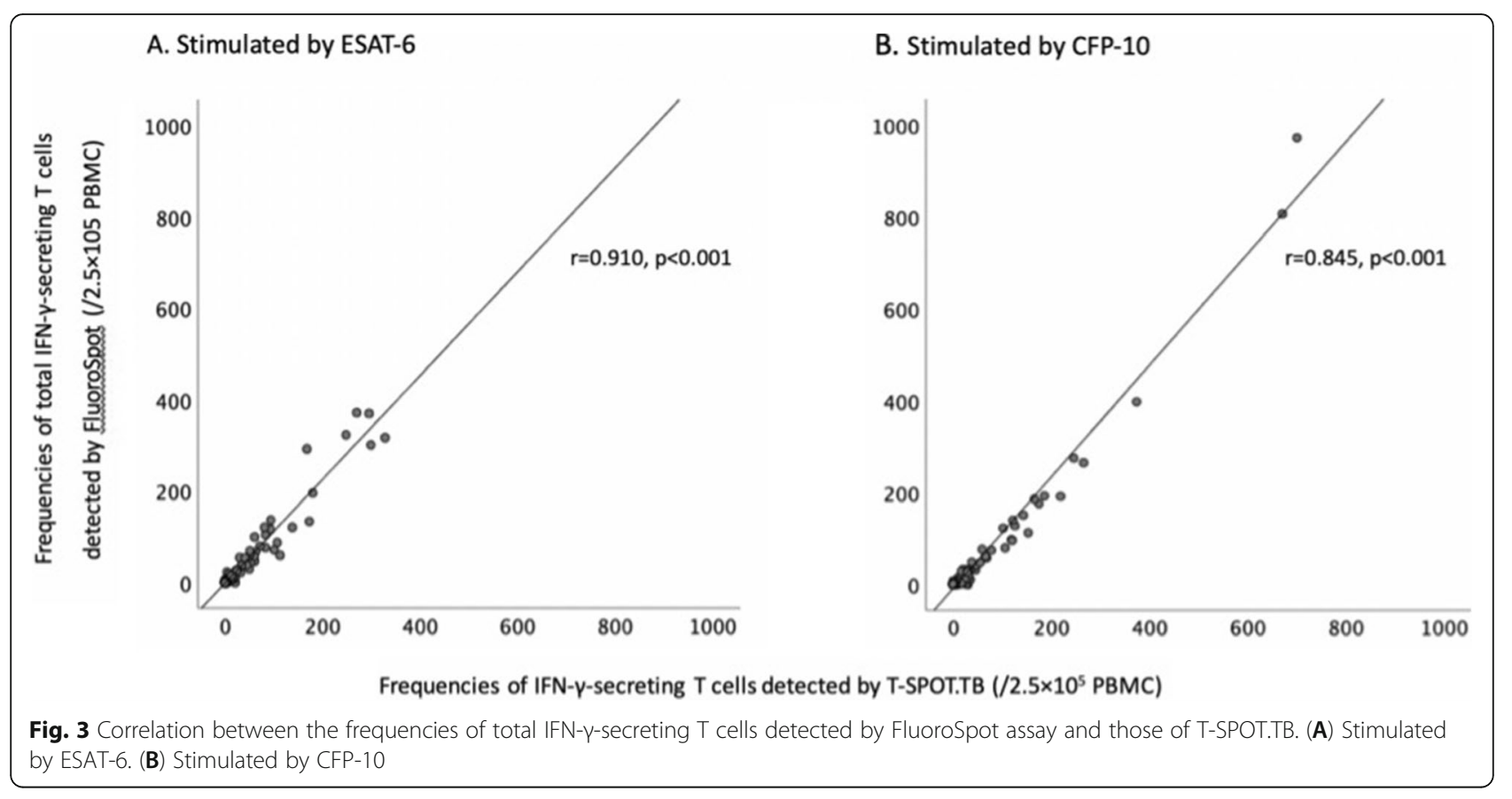

was the largest in differentiating ATB from LTBI, which was 0.970 (95\%CI, 0.894-0.996) (Fig. 4). The optimal cutoff value was 21 iSFCs $/ 2.5 \times 10^{5}$ PBMC, with a sensitivity of $96.7 \%$ (95\% CI, 82.8-99.9\%) and a specificity of 94.3\% (95\% CI, 80.8-99.3\%), respectively. The combination of ESAT-6 and CFP-10 did not improve the diagnostic accuracy of differential diagnosis of ATB and LTBI (Supplementary Table 3).
Parallel tests [10] combining the frequencies of total TNF- $\alpha$ - and total IFN- $\gamma$-secreting T cells (with optimal cutoff value: 23 iSFCs $/ 2.5 \times 10^{5}$ PBMC) improved the differential diagnostic accuracy (Table 2).

\section{Discussion}

Conventional diagnostic methods for tuberculosis are not satisfying in clinical practice as acid-fast bacilli

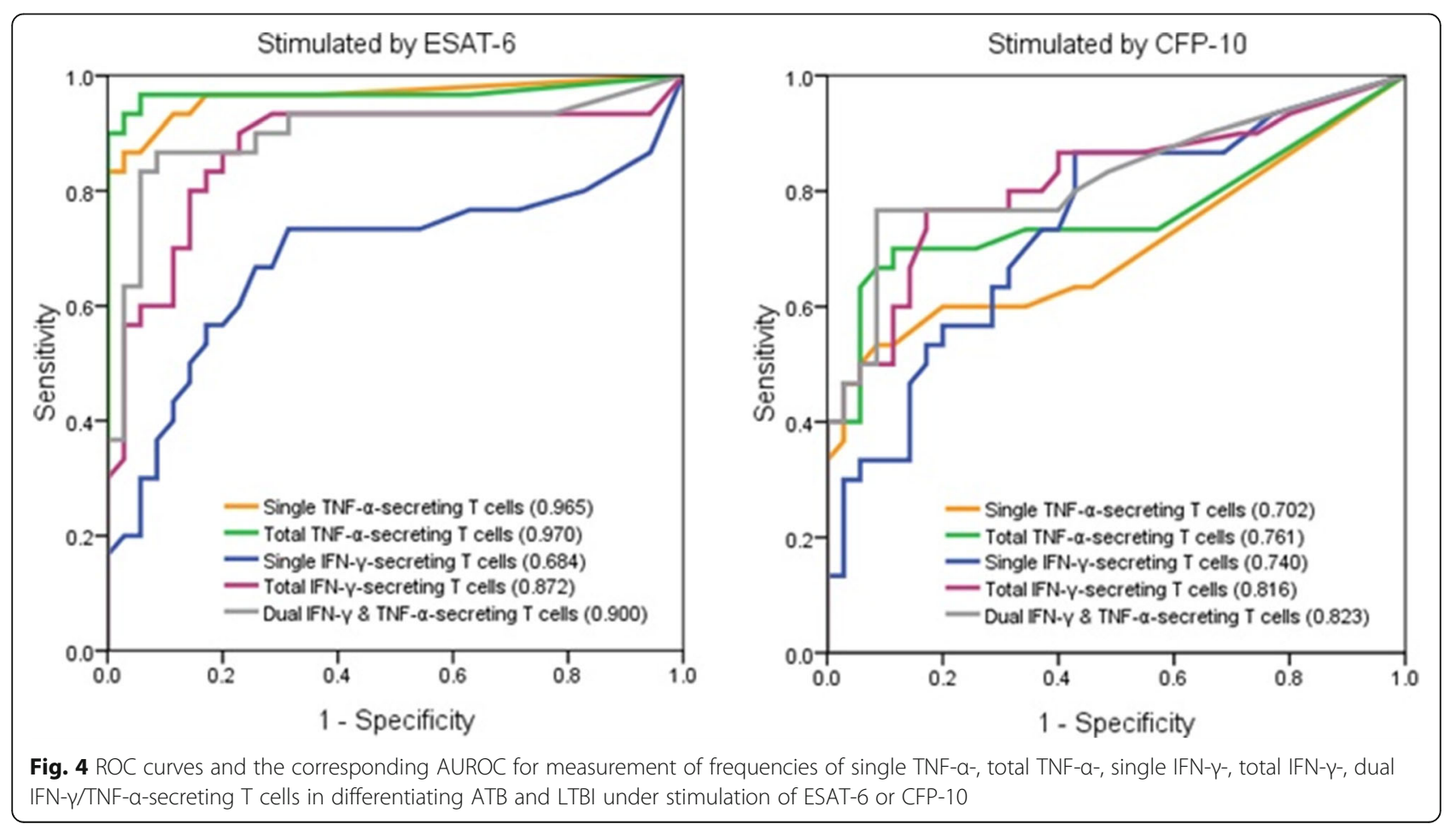


Table 2 Diagnostic accuracy of the IFN- $\gamma /$ TNF- $a$ FluoroSpot assay for differentiating ATB from LTBI (Stimulated by ESAT-6 peptide)

\begin{tabular}{|c|c|c|c|c|c|c|}
\hline & $\begin{array}{l}\text { Sensitivity } \\
(\%, 95 \mathrm{Cl})\end{array}$ & $\begin{array}{l}\text { Specificity } \\
(\%, 95 \mathrm{Cl})\end{array}$ & $\begin{array}{l}\text { PLR } \\
(95 \% \mathrm{Cl})\end{array}$ & $\begin{array}{l}\text { NLR } \\
(95 \% \mathrm{Cl})\end{array}$ & $\begin{array}{l}\text { PPV } \\
(\%, 95 \mathrm{Cl})\end{array}$ & $\begin{array}{l}\text { NPV } \\
(\%, 95 \mathrm{Cl})\end{array}$ \\
\hline Frequencies of total TNF- $a$-secreting $T$ cells & $96.7(82.8-99.9)$ & $94.3(80.8-99.3)$ & $16.92(4.40-65.08)$ & $0.04(0.01-0.24)$ & $93.6(78.6-99.2)$ & $97.1(84.7-99.9)$ \\
\hline Frequencies of total IFN- $\gamma$-secreting $T$ cells & $90.0(73.5-97.9)$ & $77.1(59.9-89.6)$ & $3.94(2.12-7.32)$ & $0.13(0.04-0.39)$ & $77.1(59.9-89.6)$ & $90.0(73.5-97.9)$ \\
\hline \multicolumn{7}{|l|}{ Parallel test } \\
\hline With the OR rule* & $96.7(82.8-99.9)$ & $74.3(56.7-87.5)$ & $3.76(2.13-6.63)$ & $0.04(0.01-0.31)$ & $76.3(59.8-88.6)$ & $96.3(81.0-99.9)$ \\
\hline With the AND rule ${ }^{\#}$ & $90.0(73.5-97.9)$ & $97.1(85.1-99.9)$ & $31.50(4.55-218.21)$ & $0.10(0.04-0.30)$ & $96.4(81.7-99.9)$ & $91.9(78.1-98.3)$ \\
\hline \multicolumn{7}{|c|}{$\begin{array}{l}\text { If the frequencies of total TNF- } \alpha-\text {-secreting T cells were greater than } 21 \text { iSFCs } / 2.5 \times 10^{5} \text { PBMC, AND more than twice as large as that of the nil control, the result of } \\
\text { TNF- } a \text { FluoroSpot assay was considered positive. If the frequencies of total IFN- }- \text {-secreting T cells were greater than } 23 \text { iSFCS } / 2.5 \times 10^{5} \text { PBMC, AND more than } \\
\text { twice as large as that of the nil control, the result of IFN- } \gamma \text { FluoroSpot assay was considered positive. } \\
\text { *The OR rule, in which the diagnosis is positive if either test is positive } \\
\text { "The AND rule, in which the diagnosis is positive only if both tests are positive } \\
\text { Abbreviations: ATB, active tuberculosis; LTBI, latent tuberculosis infection; ESAT-6, 6-kDa early-secreted antigenic target; PLR, positive likelihood ratio; NLR, } \\
\text { negative likelihood ratio; PPV, positive predictive value; NPV, negative predictive value; iSFCs, immunofluorescence spot forming cells; PBMC, peripheral blood } \\
\text { mononuclear cells }\end{array}$} \\
\hline
\end{tabular}

(AFB) smear lacks sensitivity and mycobacterial culture is time consuming [11]. Although Xpert MTB/RIF can detect MTB and rifampin-resistance mutations in several hours with high accuracy, it is estimated that 30-50\% patients failed to provide appropriate samples for the test [12]. Our previous study showed that less than $30 \%$ of patients diagnosed with ATB could be confirmed by etiology [13]. Thus, clinicians urgently need new methods to help diagnose $\mathrm{TB}$, especially for patients who cannot obtain evidence of the pathogens.

$\mathrm{T}$-cell immunity plays a critical role in controlling MTB infection [14]. IGRA works by detecting the secretion of Th1 cytokine IFN- $\gamma$ after MTB-specific antigen stimulation to diagnose TB infection [15]. In addition to IFN- $\gamma$, TNF- $\alpha$ is also involved in immunity against MTB infection. Secreted by activated dendritic cells, $\gamma \delta \mathrm{T}$ cells [16], macrophages, CD4+ as well as CD8+ T cells, TNF$\alpha$ attaches to endothelin cells and improves vascular permeability so that neutrophils and monocytes in circulation recruited by inflammation cytokines can enter infection sites and further form granuloma. TNF- $\alpha$ maintains granuloma integrity through transforming inactivated macrophage to M1 subtype, a process synergizing with IFN- $\gamma$ [17]. Clinical studies observed higher reactivation and incidence of $\mathrm{TB}$ in patients with antiTNF- $\alpha$ therapy [18-20]. Therefore, whether MTBspecific TNF- $\alpha$ secretion can contribute to the diagnosis of ATB is worthy of further study.

Our study showed that the frequencies of MTB specific IFN- $\gamma$-secreting $\mathrm{T}$ cells in the ATB group were significantly higher than those in the LTBI and HC groups. These findings were consistent with our previous research [21]. The frequencies of TNF- $\alpha$-secreting $\mathrm{T}$ cells was comparable to the results of other studies using ELISA or flow cytometry (FCM) [22-24]. The FluoroSpot assay based on the ELISPOT is more accurate compared to ELISA or FCM. The Fluorospot assay may be preferable for studies requiring the detection of lowlevel responses or qualitative results [25]. In addition, compared to FCM, FluoroSpot assay enables single-cell measurements of the actual secretion of bioactive molecules rather than intracellular analytes, which can be critical for understanding functional properties of $\mathrm{T}$ cells, as it may help in better identification of infection status [26].

Interestingly, ESAT- 6 seemed to activate T cells more effectively than CFP-10. The frequencies of TNF- $\alpha$ secreting $\mathrm{T}$ cells stimulated by ESAT- 6 were significantly higher than those stimulated by CFP-10, though no difference was detected in the IFN- $\gamma$ secretion under the stimulation of these two antigens. The immune mechanism is still unclear and remains to be further studied.

In this study, the frequencies of ESAT-6-specific total TNF- $\alpha$-secreting $\mathrm{T}$ cells might be a better potential marker for IFN- $\gamma /$ TNF- $\alpha$ FluoroSpot assay to differentiate ATB and LTBI, compared with IFN- $\gamma$-secreting T cells. Wang's study showed that the detection of. of MTB-specific TNF- $\alpha$ secretion by ELISA assay could distinguish ATB from LTBI, with a sensitivity of $72 \%$ and a specificity of $90.91 \%$ [27]. Another study evaluated the diagnostic accuracy of differentiating ATB from LTBI by combining the IGRA and the TNF- $\alpha$-release assay (TARA). Compared with IGRA only, the combination of IGRA and TARA improved the specificity without compromising the sensitivity [28]. IFN- $\gamma / \mathrm{TNF}-\alpha$ FluoroSpot assay was a new method to diagnose ATB, and only one study showed that IFN- $\gamma /$ TNF- $\alpha$ dual release assay had the best accuracy to differentiate ATB and LTBI, with a sensitivity of $84 \%$ and a specificity of $94 \%$. This was slightly different from our results, which might be due to the different inclusion criteria of the ATB patients. In addition to the microbiologically confirmed cases, the study also included clinically diagnosed TB cases, who possibly displayed different cytokine 
secretion patterns. It should also be noted that the patients' medication was not mentioned in the study, which may affect the results [29].

Furthermore, this study showed that double-testing the ESAT-6 with the CFP-10 might not increase the differential diagnostic accuracy. The result was in consistency with a study of North India population which also observed significantly higher IFN- $\gamma$ and TNF$\alpha$ response to ESAT- 6 stimulation in ATB group compared to healthy household contacts (considered as LTBI), while no significant difference was observed with CFP-10 stimulation [30]. Clifford's study showed that the level of TNF- $\alpha$ stimulated by ESAT- 6 declined significantly over the course of therapy in ATB cases, but the decrease was not significant under CFP-10 stimulation [31]. Therefore, using ESAT-6 antigen alone might reduce the cost of testing without compromising diagnostic accuracy.

Medication may disturb the cytokine secretion. Several studies of IGRAs indicated that anti-tuberculosis drugs, corticosteroids and immunosuppressants may interfere T-cell responses towards MTB antigens [13, 32-34]. Therefore, immunosuppressive therapy may also influence the efficacy of the FluoroSpot assay. In our study, one patient with rheumatoid arthritis (RA) were taking prednisone (at $15 \mathrm{mg} / \mathrm{d}$ ) when tested for both $\mathrm{T}$ SPOT.TB and FluoroSpot. Both results of the RA patients were positive and similar for overall study population. Although it is highly possible that immunosuppressive therapy did not interfere the results of the study, further research on the potential influence of the immunosuppressive therapy is needed.

Both our study and previous research found that a number of iSFCs secreting TNF- $\alpha$ in the nil control of some samples were detected, but no iSFCs secreting IFN- $\gamma$ were found [28]. A possible reason was that these spots formed without antigen stimulation may be caused by TNF-producing monocytes or dendritic cells instead of lymphocytes. TNF- $\alpha$, a monokine involved in innate immune system, was mainly secreted by activated monocytes and macrophages, yet activated dendritic cells, $\gamma \delta \mathrm{T}$ cells, CD $4+\mathrm{T}$ cells and CD8 $+\mathrm{T}$ cells can also produce TNF- $\alpha$ [16]. In addition to lymphocytes, the PBMC for FluoroSpot testing also included monocytes and DC cells, and the innate immune response in which they participated also produced TNF- $\alpha$, causing background spots in the nil control without MTB specific antigen stimulation.

However, this study has some limitations. First, we excluded patients with malignancy or undergoing TNF- $\alpha$ antagonist therapy, whose TNF- $\alpha$ secretion may be disturbed. Thus, whether IFN- $\gamma /$ TNF- $\alpha$ FluoroSpot can be applied to these population required further research. Second, the use of T-SPOT.TB as a diagnostic criterion for LTBI may lead to selection bias [35]. However, IGRA is one of the recognized methods for detecting LTBI with satisfying specificity, it is reasonable to reduce the risk of misdiagnosis in the control group. Third, the overlapping in cytokines responses still exist, which may affect the correct distinction between groups. The high background in the nil control when detecting TNF- $\alpha$ should be concerned, which may affect the results. Forth, this was only a preliminary study of diagnostic test with case-control design, making overestimation of the diagnostic accuracy highly possible, and the results need to be further verified by cross-sectional or prospective cohort studies.

\section{Conclusion}

IFN- $\gamma /$ TNF- $\alpha$ FluoroSpot assay might be helpful for the differential diagnosis of ATB and LTBI. The frequencies of ESAT-6-specific total TNF- $\alpha$-secreting T cells might be a better potential marker for IFN- $\gamma /$ TNF- $\alpha$ FluoroSpot assay, compared with IFN- $\gamma$-secreting $\mathrm{T}$ cells. The results need to be further verified by cross-sectional or prospective cohort studies.

\section{Abbreviations}

ATB: active tuberculosis; LTBI: latent tuberculosis infection; TB: tuberculosis; MTB: mycobacterium. Tuberculosis; TST: tuberculin skin test; IGRA: interferongamma release assay; PPD: purified protein derivative; BCG: Bacille CalmetteGue'rin; TNF: tumor necrosis factor; NAA: nucleic acid amplification; HC: healthy control; PBMCs: peripheral blood mononuclear cells; AIM-V: A serum free cell culture medium, Gibco ${ }^{\mathrm{TM}}$ AIM $V$ Medium liquid, Invitrogen, USA; ESAT-6: 6-kDa early-secreted antigenic target; CFP-10: 10-kDa culture filtrate protein; iSFCs: immunofluorescence spot forming cells; SFCs: spot forming cells; SD: standard deviation; IQR: interquartile range; Cls: confidence intervals; ROC curves: receiver operating characteristic curves; AUROC: areas under the ROC curves; PV: predictive value; LR: likelihood ratio; AFB: acid-fast bacilli; TARA: TNF-a-release assay

\section{Supplementary Information}

The online version contains supplementary material available at https://doi. org/10.1186/s12879-021-06351-w.

Additional file 1 Supplementary Table 1. Frequencies of single TNF$a-$, total TNF- $a-$, single IFN- $\gamma$-, total IFN- $\gamma-$, dual IFN- $\gamma / T N F-a-$ secreting $T$ cells following ESAT-6 or/and CFP-10 stimulation in ATB, LTBI and HC groups. Supplementary Table 2. Frequencies of spot-forming $T$ cell in nil control in ATB, LTBI and HC groups. Supplementary Table 3. Diagnostic accuracy of single TNF-a-, total TNF-a-, single IFN- $\gamma$-, total IFN- $\gamma$-, dual IFN- $\gamma / T N F-a-s e c r e t i n g ~ T$ cells following ESAT-6 or/and CFP-10 stimulation in differentiating ATB and LTBI.

\section{Acknowledgements}

Not applicable.

\section{Authors' contributions}

L.Z., S.W. and Z.Z. contributed equally. L.Z. and X.L. conceived and designed the study. L.Z., S.W., Y.Z. performed the experiments. Z.Z. and L.Z. interpreted the data and wrote the paper. Z.L., Z.Z. and L.X. reviewed and edited the manuscript. All authors read and approved the manuscript.

\section{Funding}

This work was supported by the National Science and Technology Major Project of the People's Republic of China [grant number 2017ZX10201302]; 
Chinese Academy of Medical Sciences Initiative for Innovative Medicine [grant number 2016-I2M-1-013]; and the Non-profit Central Research Institute fund of Chinese Academy of Medical Sciences [2017PT31010].

\section{Availability of data and materials}

The datasets used and analysed during the current study are available from the corresponding author on reasonable request.

\section{Declarations}

\section{Ethics approval and consent to participate}

The study was conducted in accordance with the Declaration of Helsinki and was approved by the Ethics Committee of PUMCH (No: S-715). Informed written consent was obtained from all patients prior to their enrollment in this study.

\section{Consent for publication}

Consent for publication was obtained from all patients prior to their enrollment in this study.

\section{Competing interests}

The authors declare that they have no competing interests.

\section{Author details}

'Division of Infectious Diseases, Peking Union Medical College Hospital, Chinese Academy of Medical Sciences \& Peking Union Medical College, Beijing 100730, China. ${ }^{2}$ Clinical Epidemiology Unit, International Epidemiology Network, Peking Union Medical College Hospital, Chinese Academy of Medical Science, Beijing 100730, China. ${ }^{3}$ Centre for Tuberculosis Research, Chinese Academy of Medical Sciences and Peking Union Medical College, Beijing, China. ${ }^{4}$ Peking Union Medical College Hospital, Peking Union Medical College, Beijing, China.

Received: 3 February 2021 Accepted: 18 June 2021

Published online: 06 July 2021

\section{References}

1. Organization WH: Global tuberculosis report 2020.

2. Organization WH: Latent tuberculosis infection: updated and consolidated guidelines for programmatic management. https://appswhoint/iris/ bitstream/handle/10665/260233/9789241550239-engpdf 2018.

3. Houben RMGJ, Dodd PJ. The global burden of latent tuberculosis infection: a re-estimation using mathematical Modelling. PLoS Med. 2016;13(10): e1002152. https://doi.org/10.1371/journal.pmed.1002152.

4. Li H, Xin H, Qian S, Li X, Zhang H, Li M, et al. Testing of tuberculosis infection among Chinese adolescents born after terminating the Bacillus Calmette-Guérin booster vaccination: subgroup analysis of a populationbased cross-sectional study. Frontiers of Medicine. 2017;11(4):528-35. https://doi.org/10.1007/s11684-017-0573-0.

5. Campbell JR, Krot J, Elwood K, Cook V, Marra F. A systematic review on TST and IGRA tests used for diagnosis of LTBI in immigrants. Mol Diagn Ther 2015;19(1):9-24. https://doi.org/10.1007/s40291-014-0125-0.

6. Clay H, Volkman HE, Ramakrishnan L. Tumor necrosis factor signaling mediates resistance to mycobacteria by inhibiting bacterial growth and macrophage death. Immunity. 2008;29(2):283-94. https://doi.org/10.1016/j. immuni.2008.06.011.

7. Solovic I, Sester M, Gomez-Reino JJ, Rieder HL, Ehlers S, Milburn HJ, et al. The risk of tuberculosis related to tumour necrosis factor antagonist therapies: a TBNET consensus statement. Eur Respir J. 2010;36(5):1185-206. https://doi.org/10.1183/09031936.00028510.

8. Janetzki S, Rueger M, Dillenbeck T. Stepping up ELISpot: multi-level analysis in FluoroSpot assays. Cells. 2014;3(4):1102-15. https://doi.org/10.3390/cells3 041102.

9. Gazagne A, Claret E, Wijdenes J, Yssel H, Bousquet F, Levy E, et al. A Fluorospot assay to detect single $T$ lymphocytes simultaneously producing multiple cytokines. J Immunol Methods. 2003;283(1-2):91-8. https://doi. org/10.1016/j.jim.2003.08.013.

10. X-h Z, McClish DK, Obuchowski NA. Statistical methods in diagnostic medicine. 2nd ed. Hoboken: Wiley; 2011.

11. Pfyffer GE, Cieslak C, Welscher HM, Kissling P, Rusch-Gerdes S. Rapid detection of mycobacteria in clinical specimens by using the automated
BACTEC $9000 \mathrm{MB}$ system and comparison with radiometric and solidculture systems. J Clin Microbiol. 1997;35(9):2229-34. https://doi.org/10.112 8/jcm.35.9.2229-2234.1997

12. Boehme CC, Nabeta P, Hillemann D, Nicol MP, Shenai S, Krapp F, et al. Rapid molecular detection of tuberculosis and rifampin resistance. N Engl J Med. 2010;363(11):1005-15. https://doi.org/10.1056/NEJMoa0907847.

13. Zhang L, Shi X, Zhang Y, Zhang Y, Huo F, Zhou B, et al. Analysis of Factors Influencing Diagnostic Accuracy of T-SPOT.TB for Active Tuberculosis in Clinical Practice. Sci Rep. 2017;7(1):7764.

14. Jasenosky LD, Scriba TJ, Hanekom WA, Goldfeld AE. T cells and adaptive immunity to Mycobacterium tuberculosis in humans. Immunol Rev. 2015; 264(1):74-87. https://doi.org/10.1111/imr.12274.

15. Lalvani A. Diagnosing tuberculosis infection in the 21st century: new tools to tackle an old enemy. Chest. 2007;131(6):1898-906. https://doi.org/10.13 78/chest.06-2471.

16. Meraviglia S, El Daker S, Dieli F, Martini F, Martino A. Gammadelta T cells cross-link innate and adaptive immunity in Mycobacterium tuberculosis infection. Clin Dev Immunol. 2011;2011:587315.

17. Sahu SK, Kumar M, Chakraborty S, Banerjee SK, Kumar R, Gupta P, et al. MicroRNA 26a (miR-26a)/KLF4 and CREB-C/EBPbeta regulate innate immune signaling, the polarization of macrophages and the trafficking of Mycobacterium tuberculosis to lysosomes during infection. PLoS Pathog. 2017;13(5):e1006410. https://doi.org/10.1371/journal.ppat.1006410.

18. Keane J, Gershon S, Wise RP, Mirabile-Levens E, Kasznica J, Schwieterman WD, et al. Tuberculosis associated with infliximab, a tumor necrosis factor alpha-neutralizing agent. N Engl J Med. 2001;345(15):1098-104. https://doi. org/10.1056/NEJMoa011110.

19. Lee EH, Kang YA, Leem AY, Park MS, Kim YS, Kim SK, et al. Active tuberculosis incidence and characteristics in patients treated with tumor necrosis factor antagonists according to latent tuberculosis infection. Sci Rep. 2017;7(1):6473. https://doi.org/10.1038/s41598-017-06899-1.

20. Cao BL, Qasem A, Sharp RC, Abdelli LS, Naser SA. Systematic review and meta-analysis on the association of tuberculosis in Crohn's disease patients treated with tumor necrosis factor-alpha inhibitors (anti-TNFalpha). World J Gastroenterol. 2018;24(25):2764-75. https://doi.org/10.3748/wjg.v24.i25.2764.

21. Zhang L, Cheng X, Bian S, Song Y, Li Q, Gao M, et al. Utility of Th1-cell immune responses for distinguishing active tuberculosis from non-active tuberculosis: a case-control study. PLoS One. 2017;12(5):e0177850. https:// doi.org/10.1371/journal.pone.0177850.

22. Sutherland JS, Adetifa IM, Hill PC, Adegbola RA, Ota MO. Pattern and diversity of cytokine production differentiates between Mycobacterium tuberculosis infection and disease. Eur J Immunol. 2009;39(3):723-9. https:// doi.org/10.1002/eji.200838693.

23. Sutherland $J S$, de Jong $B C$, Jeffries DJ, Adetifa IM, Ota MO. Production of TNF-alpha, IL-12(p40) and IL-17 can discriminate between active TB disease and latent infection in a west African cohort. PLoS One. 2010;5(8):e12365. https://doi.org/10.1371/journal.pone.0012365.

24. Harari A, Rozot V, Bellutti Enders F, Perreau M, Stalder JM, Nicod LP, et al. Dominant TNF-alpha+ Mycobacterium tuberculosis-specific CD4+ T cell responses discriminate between latent infection and active disease. Nat Med. 2011:17(3):372-6. https://doi.org/10.1038/nm.2299.

25. Karlsson AC, Martin JN, Younger SR, Bredt BM, Epling L, Ronquillo R, et al. Comparison of the ELISPOT and cytokine flow cytometry assays for the enumeration of antigen-specific T cells. J Immunol Methods. 2003;283(1-2): 141-53. https://doi.org/10.1016/j.jim.2003.09.001.

26. Lehmann PV, Zhang W. Unique strengths of ELISPOT for T cell diagnostics. Methods Mol Biol. 2012;792:3-23. https://doi.org/10.1007/ 978-1-61779-325-7 1

27. Wang $F$, Hou H, Xu L, Jane M, Peng J, Lu Y, et al. Mycobacterium tuberculosis-specific TNF-alpha is a potential biomarker for the rapid diagnosis of active tuberculosis disease in Chinese population. PLOS One. 2013;8(11):e79431. https://doi.org/10.1371/journal.pone.0079431.

28. Kim JY, Park JH, Kim MC, Cha HH, Jeon NY, Park SY, et al. Combined IFN-gamma and TNF-alpha release assay for differentiating active tuberculosis from latent tuberculosis infection. J Inf Secur. 2018;77(4): 314-20.

29. Kim JY, Kang YA, Park JH, Cha HH, Jeon NY, Lee SW, et al. An IFN-gamma and TNF-alpha dual release fluorospot assay for diagnosing active tuberculosis. Clin Microbiol Infect. 2020;26(7):9228-34.

30. Singh SB, Biswas D, Rawat J, Sindhwani G, Patras A, Devrani S, et al. Ethnicity-tailored novel set of ESAT- 6 peptides for differentiating active and 
latent tuberculosis. Tuberculosis (Edinb). 2013;93(6):618-24. https://doi.org/1 0.1016/.jtube.2013.08.001.

31. Clifford V, Tebruegge M, Zufferey C, Germano S, Forbes B, Cosentino L, et al. Mycobacteria-specific cytokine responses as correlates of treatment response in active and latent tuberculosis. J Inf Secur. 2017;75(2):132-45.

32. Hu X, Li WP, Meng C, Ivashkiv LB. Inhibition of IFN-gamma signaling by glucocorticoids. J Immunol. 2003;170(9):4833-9. https://doi.org/10.4049/ jimmunol.170.9.4833.

33. Carrara S, Vincenti D, Petrosillo N, Amicosante M, Girardi E, Goletti D. Use of a T cell-based assay for monitoring efficacy of antituberculosis therapy. Clin Infect Dis. 2004;38(5):754-6. https://doi.org/10.1086/381754

34. Wong SH, Gao Q, Tsoi KK, Wu WK, Tam LS, Lee N, et al. Effect of immunosuppressive therapy on interferon gamma release assay for latent tuberculosis screening in patients with autoimmune diseases: a systematic review and meta-analysis. Thorax. 2016;71(1):64-72. https://doi.org/10.1136/ thoraxjnl-2015-207811.

35. Doan TN, Eisen DP, Rose MT, Slack A, Stearnes G, McBryde ES. Interferongamma release assay for the diagnosis of latent tuberculosis infection: a latent-class analysis. PLoS One. 2017;12(11):e0188631. https://doi.org/10.13 71/journal.pone.0188631.

\section{Publisher's Note}

Springer Nature remains neutral with regard to jurisdictional claims in published maps and institutional affiliations.

Ready to submit your research? Choose BMC and benefit from:

- fast, convenient online submission

- thorough peer review by experienced researchers in your field

- rapid publication on acceptance

- support for research data, including large and complex data types

- gold Open Access which fosters wider collaboration and increased citations

- maximum visibility for your research: over $100 \mathrm{M}$ website views per year

At BMC, research is always in progress.

Learn more biomedcentral.com/submissions 